\title{
Horizontal root fracture in the apical third: case report
}

\author{
Fratura radicular horizontal no terço apical: relato de caso
}

\author{
Klaus Souza SANTOS ${ }^{1}$ \\ Mário Alfredo Silveira MIRANZI² \\ Benito André Silveira MIRANZI ${ }^{3}$ \\ Sílvia França SANTOS ${ }^{4}$ \\ Almir José Silveira MIRANZI ${ }^{3}$
}

\section{ABSTRACT}

This article presents a clinical case of horizontal root fracture, in an adult patient, male, in the apical third, due to the practice of sports, which, along with other factors, has led to pulp necrosis. Initially, the patient sought emergency care, and then he underwent treatment by endodontics, using calcium hydroxide between sessions. After a monitoring period, root canal obturation was performed and the tooth is clinically and radiographically stable 2 years after the trauma. In this case, monitoring is long-lasting, divided into 12-month periods for 10 years, with clinical and radiographic evaluation. Dental fracture in children and teenagers from 10 to 14 years is very common, especially during the practice of sports and recreation activities. It is expected that young male individuals have greater propensity to damage their teeth than young female individuals. Maxillary central incisor is the tooth most commonly involved, and it often evolves to pulp necrosis after trauma.

Indexing terms: Adolescent. Child. Endodontics. Tooth Injuries.

\section{RESUMO}

Este artigo apresenta um caso clínico de fratura radicular horizontal, em paciente adulto, do sexo masculino, no terço apical, decorrente de prática esportiva, que, somado a outros fatores, levou à necrose pulpar. A Inicialmente, o paciente procurou atendimento de urgência, depois foi submetido a tratamento por endodontia, com utilização de hidróxido de cálcio entre as sessões. Inicialmente, o paciente procurou atendimento de urgência, e, posteriormente, recebeu tratamento por meio da endodontia, com utilização entre sessões de hidróxido de cálcio. Após um período de acompanhamento, foi realizada a obturação do conduto radicular e o elemento dental encontra-se clínica e radiograficamente estável passados dois anos do traumatismo. O acompanhamento deste caso será de longa duração, dividido em períodos de 12 meses por 10 anos, com avaliação clínica e radiográfica. A ocorrência de fratura dental em crianças e adolescentes de 10 a 14 anos é muito comum, principalmente durante prática esportiva e atividades de recreação. Pode-se esperar que jovens do sexo masculino tenham uma maior propensão a lesar seus dentes em comparação aos indivíduos do sexo feminino. O incisivo central superior é o dente mais comumente envolvido e, com frequência, após o trauma, evolui para necrose pulpar.

Termos de indexação: Adolescente. Criança. Endodontia. Traumatismos dentários.

\section{INTRODUCTION}

The incidence of oral and dental trauma affecting anterior teeth increases significantly, upper central incisors are mentioned by researchers as the most likely ${ }^{1}$ and cases usually fall within the age group from 10 to 14 years ${ }^{2-3}$. According to Tarján \& Gábris ${ }^{4}$, the most frequent causes are falls, followed by strokes of various origins, car accidents, trauma in the practice of sports, fights, etc., which vary by sex. Venturini et al. ${ }^{5}$ think that horizontal fractures in anterior teeth derive from severe trauma.
Root fractures usually affect the middle third, accounting for about 20 to $25 \%$ of cases, and there can be necrosis of tooth pulp due to disruption of the nervousvascular bundle ${ }^{2}$. According to Andreasen \& Andreasen ${ }^{1}$, the signs of pulp necrosis are: changes in crown color, negative sensitivity test, and presence of periapical bone rarefaction in radiography. Pulp necrosis associated with trauma can lead to changes in hydrogen pressure $(\mathrm{pH})$ and contamination, causing tissue resorption. Estrela \& Figueiredo ${ }^{6}$ evaluated the chemical and mechanical effect of calcium hydroxide paste inserted into root canals affected by chronic apical periodontitis 5 .

\footnotetext{
${ }^{1}$ Centro Federal de Educação Tecnológica de Minas Gerais. Av. Amazonas, 5253, Nova Suíça, 30421-169, Belo Horizonte, MG, Brasil. Correspondência para / Correspondence to: KS SANTOS. E-mail: <klasantos@hotmail.com.br>.

${ }^{2}$ Universidade Federal do Triângulo Mineiro, Departamento de Medicina Social. Uberaba, MG, Brasil.

${ }^{3}$ Universidade de Uberaba. Uberaba, MG, Brasil.

${ }^{4}$ Universidade Federal de Minas Gerais. Belo Horizonte, MG, Brasil.
} 
Containment of traumatized tooth can preserve crown vitality and avoid resorption or migration.

This article presents a case of horizontal root fracture in the apical third treated by endodontic procedures, using calcium hydroxide between sessions.

According to Andreasen \& Andreasen ${ }^{1}$ and Caprioglio \& lavagnoli ${ }^{7}$, root fractures in permanent teeth predominantly affect the upper central incisors in individuals aged between 11 and 20 years and 20 to $44 \%$ of cases evolve to pulp necrosis. In cases of root fracture, researchers recommend, in addition to other measures, instant fragment repositioning and strict containment within a 2 to 3 -month period.

Tosta \& Imura $^{8}$ confirmed the importance of resorting to containment in root fracture of permanent teeth, because otherwise the pulp tissue of the crown fragment tends to become necrotic. Examining a patient affected by dental trauma is key to execute a treatment plan.

Rosenberg et al. ${ }^{9}$ compared root resistance after application of calcium hydroxide paste and these authors concluded that resistance increases depending on the medication time.

Fidel et al. ${ }^{10}$ presented a case of tooth fracture in a young patient, treated with calcium hydroxide; medication change must occur during the apexification process. After endodontic therapy, the tooth was monitored for 12 years to demonstrate success.

Mehlman ${ }^{11}$ recommended that teeth affected by trauma must be monitored to check root vitality for at least three months after the accident. Teeth with viable pulp should be maintained without endodontic therapy, while, given the negative test for vitality, the canal must be immediately opened, cleaned, and filled with calcium hydroxide.

According to Saoud et al. ${ }^{12}$ traumatized teth with horizontal root fractures resulting in pulp necrosis and inflammtory root resortions are traditionally, treated with conventional root canal therapy.

According to Mesgarzadeh et al. ${ }^{13}$, early procedures in dental trauma are critical in terms of the time and quality of repair. Just as Qin ${ }^{14}$ concluded that the evaluation of pulp damage is key to define treatment.

Altun et al. ${ }^{15}$ reported that the tooth most affected by trauma was maxillary central incisor $(88.2 \%)$; the most common situation was walking or running (40.3\%); and the most common types of fracture involved enamel (44.6\%). Bendo et al. ${ }^{16}$ found that the age most susceptible to dental trauma ranged from 9 to 14 years. In turn, AdekoyaSofowora et al. ${ }^{17}$ observed that most accidents occur at school (60.4\%), followed by households (26.4\%), and these researchers regard trauma as a public health problem.

Calcium hydroxide paste has a mineralizing action, due to high $\mathrm{pH}$, and it can stimulate deposition of minerals on the fracture line, besides promoting maintenance of cortical alveolar bone ${ }^{6}$. The effect of this medicine depends on dissociation of compound into hydroxyl and calcium ions. An oily vehicle promotes slow and continuous diffusion of these ions. Researchers suggest, in cases of root fractures with pulp necrosis, periodic changes every 60 days. Also, Andreasen \& Andreasen ${ }^{1}$ stress that, in cases requiring endodontic intervention on root fractures, we may initiate therapy using calcium hydroxide. After successive changes in this medicine, a hard tissue barrier can be formed in the apical region of the crown, a fact that allows root canal obturation. Calcium hydroxide, due to its mineralizing and bactericidal properties, is widely accepted and used to repair horizontal root fractures. However, recently, the option of using mineral trioxide aggregate (MTA) emerged² .

\section{CASE REPORT}

A male patient, 44 years old, was referred to a public oral health service for endodontic treatment of maxillary central incisor, reporting a dental trauma history. Initially, anamnesis revealed the occurrence of dental trauma during the practice of sports: he was 'elbowed' in the anterior area of the mouth, in the upper right incisor. Soon after the incident, he sought urgent care reporting pain symptoms in the anterosuperior region. Clinically, the tooth exhibited mobility, without alveoli displacement, a situation that suggests concussion or subluxation. The therapy established was analgesic and anti-inflammatory prescription, patient guidance, and control. Four months after trauma, darkening was found in the crown of tooth number 11 and the patient was referred to endodontic evaluation.

In the initial appointment, electrical and thermal tooth tests were conducted, with a negative response. In addition, the tooth had grade I mobility during palpation and horizontal and vertical impact tests showed positive responses. Radiographic examination revealed root fracture in the apical third, with signs of root resorption (Figure 1). Thus, the diagnosis of tooth number 11 was suggestive of pulp necrosis, resulting from buccodental trauma with fracture in the root apical third. After opening pulp chamber, mucus bloody intracanal exudate was observed. There was gradual canal neutralization and endodontic therapy was established with periodic changes in calcium 
hydroxide paste associated with paramonochlorophenol. After each paste change, a periapical radiograph was performed to check root canal filling (Figure 2).

After an 18 month-period, a barrier was clinically found close to the fracture line, as demonstrated when penetrating the canal with an endodontic instrument. Apical resistance to an endodontic instrument (K-file type) number 60 and absence of signs and symptoms added to radiographic data enabled root canal obturation close to the fracture line; apical fragment was kept (Figure 2). Then, the patient was referred to tooth repair and he was advised to come back for clinical and radiographic control. After 5 months, the first control, absence of signs and symptoms was clinically found, with negative percussion, palpation, and mobility. Radiographically, there were lamina dura and rounded fracture margins (Figure 3). A second control (6 months) was carried out, and no clinical and radiographic changes were found. Later, a third control was performed without evidence of changes.

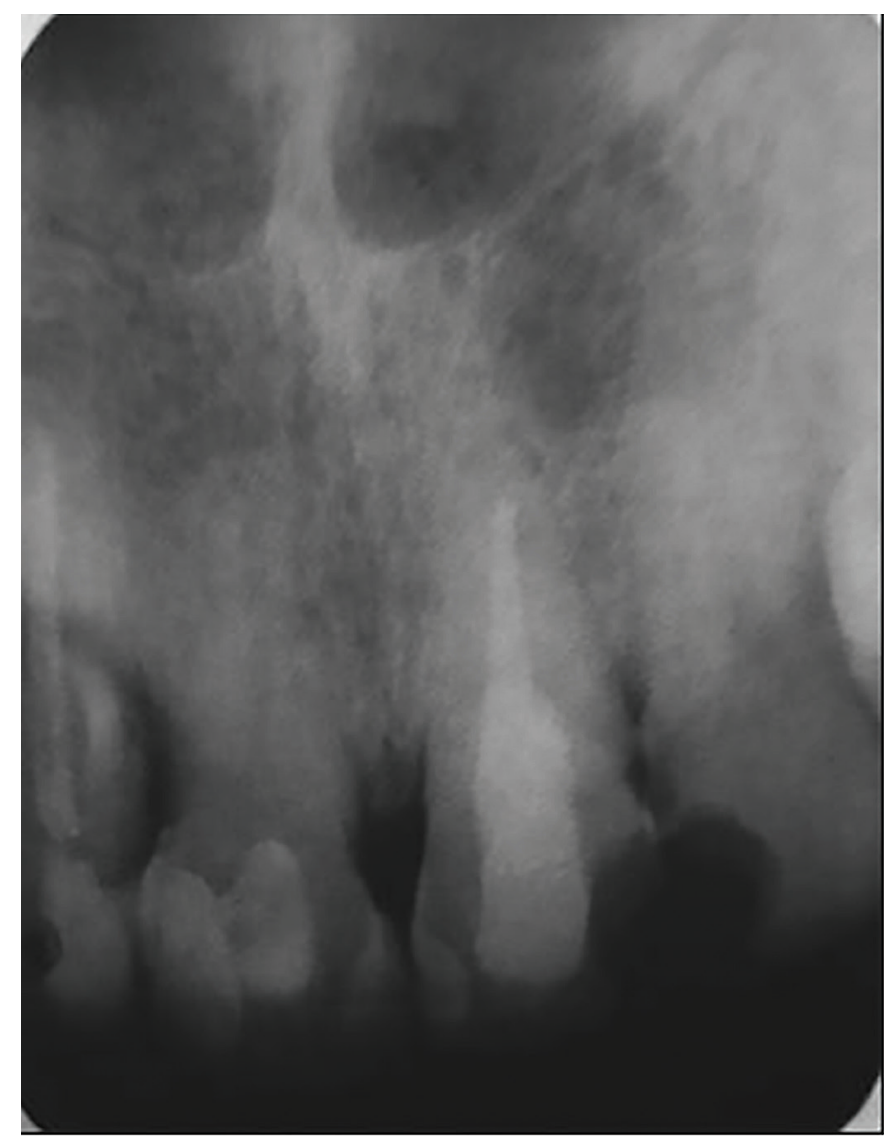

Figure 1. Longitudinal fracture in the apical third.

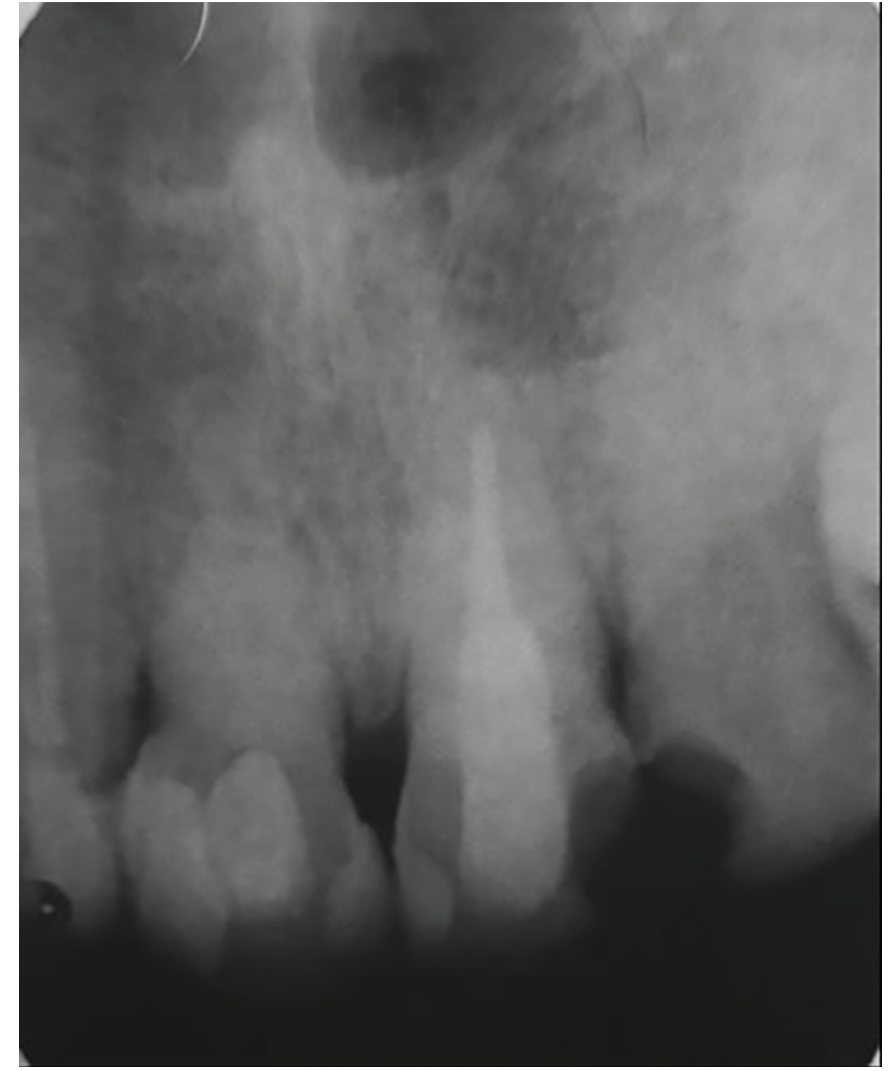

Figure 2. Canal filling with calcium hydroxide.

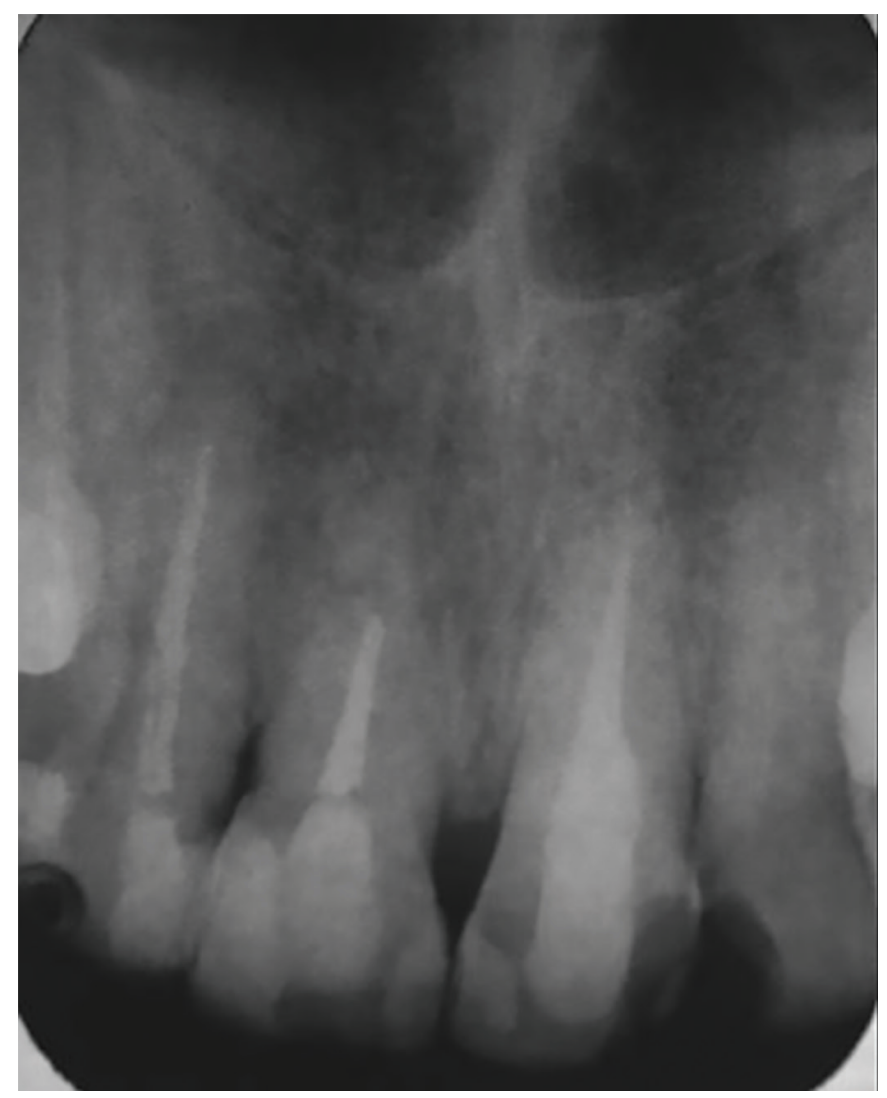

Figure 3. Crown obturation. 


\section{DISCUSSION}

Emergency care provided to a victim of trauma is important for successful therapy. The longer length of time after trauma and before the first procedure, the more difficult the repair process becomes. Early manipulation of fragments may facilitate repair. In this clinical case, the patient had already been provided with care, but he showed symptoms and, after diagnosis and treatment planning, access surgery was undertaken and the diagnosis of pulp necrosis could be confirmed. Radiographic examination revealed presence of horizontal root fracture in the apical third (Figure 1).

In order to achieve the desired success, there is a need for fast and accurate diagnosis by the professional. Thus, the dental surgeon must be aware of clinical and radiographic information.

According to Andreasen \& Andreasen ${ }^{1}$, the initial approach in cases of root fracture is crown repositioning, when displacement occurs, and splinting.

In cases of pulp necrosis due to root fracture, just as in this clinical case, a therapy inducing simultaneous formation of hard tissue barrier at the fracture site must be established ${ }^{7-8}$. Calcium hydroxide, due to its action mechanism, is the drug of choice. This action is related to dissociation of its ions, the latter have mineralizing and bactericidal effects; manipulation of calcium hydroxide in a semi-oily vehicle promotes a dissociation into ions that enables the induction of perifracture hard tissue and increased $\mathrm{pH}$ potentiates its bacteriostatic action, by promoting clearance of the infectious process and stimulating tissue repair6,9-13.

Time is key to enable effectiveness of intracanal medication. Thus, a change in calcium hydroxide within 60 days is recommended. It seems that the vehicle type

\section{REFERENCES}

1. Andreasen JO, Andreasen FM. Texto e atlas colorido de traumatismo dental. Porto Alegre: Artmed; 2001.

2. Naidoo S, Sheiham A, Tsakos G. Traumatic dental injuries of permanent incisors in 11- to 13-year-old South African schoolchildren. Dent Traumatol. 2009;25(2):224-8. doi: 10.1111/j.1600-9657.2008.00749.x

3. Cavalcanti AL, Bezerra PK, Alencar CR, Moura C. Traumatic anterior dental injuries in 7- to 12-year old Brasilian children. Dent Traumatol. 2009;25(2):198-202. doi: 10.1111/j.16009657.2008.00746.x associated with the drug is related to diffusion of hydroxyl ions. An oily vehicle favors a slower release of these ions, and this is suggested for the last phase of medication use.

In a successful endodontic therapy of tooth root fracture, the formation of a hard tissue barrier is observed apically to the crown ${ }^{1}$. Along with this clinical finding (Figure 3), there is obliteration of the apical canal. Monitoring this tooth must go on for a long time and Fidel et al. ${ }^{10}$ recommended that radiographs are repeated annually for 12 years.

Radiographic evaluation provides significant information to check apical repair. The vast majority of root fracture cases can be solved through repositioning, containment, and follow-up. However, in the clinical case described, endodontic therapy with calcium hydroxide has proved to be effective, as shown by clinical and radiographic findings ${ }^{2}$.

\section{CONCLUSION}

According to the theoretical framework adopted, we may conclude that, due to horizontal root fracture in the apical third, endodontic therapy must be undertaken in multiple sessions with intracanal medication, using calcium hydroxide and crown obturation after root apexification.

\section{Collaborators}

KS SANTOS was in charge of the diagnosis, planning, and execution of this clinical case, also contributing to prepare the manuscript. MAS MIRANZI contributed to monitor the patient and prepare the manuscript. BAS MIRANZI, SF SANTOS, and AJS MIRANZI contributed to monitor the patient, review the literature, and prepare the manuscript.

4. Tarján I, Gábris K. Changing approaches to traumatic injuries to primary and permanent teeth based on the reports published in "Fogorvosi Szemle"in the past 100 years. Fogorv Sz. 2009;102(1):3-6.

5. Venturini $\mathrm{MDH}$, Belluzzo AM, Ribeiro RD. Fratura horizontal tratada com hidróxido de cálcio: relato de caso clínico. Rev Odontol UNICID. 2000;12(1):47-53

6. Estrela C, Figueiredo JP. Endodontia: princípios biológicos e mecânicos. $2^{a}$ ed. São Paulo: Artes Médicas; 2004.

7. Caprioglio D, Lavagnoli G. Root fracture and tooth luxation. Endoorthodontic technic after 15 years. Dent Cadmos. 1989;57(3):3250 . 
8. Tosta M, Imura N. Reparação de fratura radicular horizontal em incisivo central superior. Rev Assoc Paul Cir Dent. 2000;54(5):36870.

9. Rosenberg B, Murray PE, Namerow K. The effect of calcium hydroxide root filling on dentin fracture strength. Dent traumatol. 2007;23(1):26-9. doi: 10.1111/j.1600-9657.2006.00453.x

10. Fidel RA, Carvalho RG, Varela $\mathrm{CH}$, Letra A, Fidel SR. Complicated crown fracture: a case report. Braz Dent J. 2006;17(1):83-6. 10.1590/S0103-64402006000100019

11. Mehlman ES. Traumatic injuries of the teeth: current treatment modalities. Dent Today. 2003;22(7):98-101.

12. Saoud TM, Mistry S, Mahler B, Sigurdsson A, Lim LM. Regenerativa endodontic procederes for traumatized teto after horizontal root fracture, avulsion, and perforating root resortion. J Endod. 2016 Oct;42(10):1476-82. doi: 10.1016/j.joen.2016.04.028.

13. Mesgarzadeh $A H$, Shahamfar $M$, Hefzollesan A. Evaluating knowledge and attitudes of elementary school teachers on emergency management of traumatic dental injuries: study in an Iranian urban area. Oral Health Prev Dent. 2009;7(3):297-308.

14. Qin M. Pulp treatment of young permanent teeth after traumatic dental injury. Hua Xi Kou Qiang Yi Xue Za Zhi. 2009;27(3):23740.
15. Altun C, Ozen B Esenlik E, Guven G, Gurbuz T, Acikel C, et al. Traumatic injuries to permanent teeth in Turkish children, Ankara. Dent Traumatol. 2009;25(3):309-13.

16. Bendo CB, Scarpelli AC, Vale MP, Araújo Zarzar PM. Correlation between socioeconomic indicators and traumatic dental injuries: a qualitative critical literature review. Dent Traumatol. 2009;25(4):420-5. doi: 10.1111/j.1600-9657.2009.00803.x

17. Adekoya-Sofowora CA, Adesina OA, Nasir WO, Oginni AO, Ugboko VI. Prevalence and causes of fracture permanent incisors in 12-year-old suburban Nigerian schoolchildren. Dent Traumatol. 2009;25(3):314-7. doi: 10.1111/j.1600-9657.2008.00704.x

Received on: 17/10/2015

Final version resubmitted on: 6/4/2016

Approved on: 12/6/2016 